\title{
22 Street vendors and regulations
}

\author{
Sally Roever
}

The state of street vending in cities across the world today is not much different than it was 20 years ago: while street vendors contribute to cities by creating jobs, generating revenue for local governments, and "bring[ing] life to dull streets", they are also subjects of regulation - and sometimes eviction - due to concerns around congestion in public spaces, competition with off-street businesses, and health and sanitation challenges (Bromley 2000). What is different now is that recent research has produced a much more fine-grained understanding of the components of regulation and, significantly, the urban policies and politics behind them.

This chapter outlines key insights from the past 20 years of research on four areas of regulation as they apply to street trade: (1) licensing regimes; (2) spatial regulations; (3) enforcement provisions; and (4) taxation. It then highlights important lessons from the day-to-day realities of street trade that are underresearched and points to promising areas for future research, drawing on the field experience of Women in Informal Employment: Globalizing and Organizing (WIEGO) and StreetNet International, the global federation of street vendor organisations.

\section{Street vending regulations: a global view}

\section{Licensing regimes}

The main difference between a licensing system and a permitting system is that a licensing system regulates the right to undertake the activity, while a permitting system regulates the space in which the activity takes place (Horn 2018). In many cities, by-laws require street vendors to have a licence in order to trade; trading without a licence is thus considered illegal. Through this system, many local authorities make explicit their intent to control the number of street vendors by limiting the number of licences issued.

With the criminalisation of vending without a licence built into the legal structure, and the limit on available licences built into the policy structure, authorities can then selectively enforce the by-law through fines or arrests when it is politically convenient to get rid of vendors, and relax enforcement when it is 


\section{Sally Roever}

politically convenient to allow them to work. These practices, and the policies and political coalitions behind them, are now well documented in cities as diverse as Guangzhou (Xue and Huang 2015), Bogotá (Donovan 2008), Mumbai (Anjaria 2006) and Johannesburg (Bénit-Gbaffou 2015), among others.

Historically, licensing regimes have been used in efforts to control economic activity under centralised planning paradigms (as in colonial-era legislation in India), but under present-day norms of deregulation, licensing and enforcement practices often are informed not so much by a planning paradigm as by political expediency.

\section{Spatial regulations}

Regulations designed to keep street vendors out of certain public spaces are more centrally linked to prevailing urban governance paradigms than licensing systems. How these paradigms manifest themselves in policy and practice ranges from locality-specific permitting regimes that control who can vend in which space, to relocation projects designed to "graduate" street vendors to off-street commercial premises, to outright evictions, sometimes on a mass scale and sometimes violent - the latter of which are now routinely documented via social media.

There is now a well-established research trajectory analysing these efforts to control public space, particularly in the historic centres of Latin American cities (Swanson 2007; Crossa 2009; Mackie, Bromley and Brown 2014) and the central business districts of African cities (Skinner 2008; Kamete 2012; Morange 2015). This research examines the political coalitions behind clearances of public space. Building on this set of studies, an important recent advance is the examination of the conceptual and theoretical frames that inform those coalitions, drive their discourses and define their policy choices.

For example, Aliaga Linares (2018) shows that street vending regulation in Lima, Peru, and Bogotá, Colombia, reflects different theoretical views of informality under different national political economy contexts. During the import substitution industrialisation period from the 1970s to the mid-1980s, both cities adopted a dualist perspective on the informal economy under socialist urban policy regimes; this produced a tolerant regulatory approach to street vending involving a mix of licensing, zoning and support for political participation. Under structural adjustment policies between the mid-1980s and the late-1990s, the dualist view was replaced with a legalist view, and neoliberalism replaced municipal socialism in both cities (Goldfrank and Schrank 2009), leading to far more restrictive regulations. From 2000 to 2010, the two cities diverged. In Lima, local government politicians embraced a stronger neoliberal approach that framed street vendors as entrepreneurs, leading to policies compelling them to relocate to private commercial spaces at their own expense through group savings schemes. In Bogotá, a shift back to municipal socialism produced a view of street vendors as workers instead of entrepreneurs, which - backed by constitutional court rulings in favour of vendors' right to work - led to more promotional policies. 


\section{Enforcement provisions}

Many researchers have noted the gap between the pervasiveness of street vending regulations around the world and their enforcement in practice. This gap has been connected to the considerable monetary and human resources required to enforce a hopelessly complex regulatory structure (New York City Independent Budget Office 2010); the electoral costs of enforcement (Holland 2015); and the regulatory spaces that enable local officials to use their positions of relative power over vendors to undertake selective enforcement (Roever 2016). Enforcement via low-level harassment is now well documented in many cities; there is even a map of "bribes per square meter" among street vendors for downtown São Paulo (Itikawa 2006).

Within the regulations themselves, enforcement provisions commonly allow for fines and merchandise confiscations, as well as licence revocations and even arrests. These provisions have a significant impact on street vendors' income, productivity and assets (Roever and Skinner 2016). Interestingly, legal challenges to merchandise confiscations have begun to emerge; for example, a street vendor in Durban, with the support of the Legal Resources Centre, won a 2014 court case challenging the city's power to impound merchandise and seeking compensation (Dobson and Quazi 2015).

\section{Taxation}

Notwithstanding the common assumption that street vendors do not pay taxes of any kind, regulatory schemes often incorporate some mix of taxes, levies and fees. In West African cities, for example, where there is a high density of market trade, there is a correspondingly high rate of taxes, levies and fees in markets collected on a daily, monthly and/or yearly basis (Adamtey 2015; Horn 2018). Street vending generates tax revenue both directly and indirectly; in Los Angeles, for example, the potential direct, indirect and induced tax revenue generated through vendor sales throughout the retail chain is estimated to be $\$ 124$ million (Liu, Burns and Flaming 2015: 6).

Recent studies have begun to unpack the different kinds of taxes, levies and fees and the kinds of street vendors to which they are applicable. Entitlement fees and valuation fees written into national tax laws, for example, can shape the way municipalities charge street vendors for the use of public space (Roever 2016). Income tax is rarely applicable to low-income street vendors because their earnings fall under the threshold for income taxation; yet many street vendors pay value added tax (VAT) on the goods they purchase, without any way to pass on the cost of VAT to consumers (Skinner, Reed and Harvey 2018). A broader literature documents the range of efforts to "tax the informal sector" (e.g., Dube and Casale 2016). Recently, researchers have begun to examine street vendors' perceptions of the fairness of those taxes (Rogan $2018 b$ ) within the context of the broader literatures on municipal finance and tax justice. 


\section{Sally Roever}

\section{Street vending realities and future research}

\section{Organising and regulation}

The extensive literature on street vending regulation reviewed above reflects a heavy emphasis on the state, with less attention paid to the dynamics of organising. Yet the reality is that street vendor organising is centrally related to regulation, whether the organising itself is formal or informal, and whether or not the main source of regulation is the state. The global movement of street vendor organisations coordinated through StreetNet International is increasingly pushing the boundaries of regulation, primarily by expanding the capacity of street vending organisations to engage in negotiation and collective bargaining (Carré, Horn and Bonner 2018). Thus, efforts by street vendor organisations to engage with different government entities in order to develop a harmonised approach to street vending regulation represent a key research frontier.

However, these engagements often do not take place in neatly bound forums or easily defined spaces. Rather, they evolve slowly in a variety of different modalities, with as many cancelled meetings as meetings held, as many unanswered invitations as accepted ones, as many false starts and setbacks as agreements made - all in the context of changing political currents and a constant rotation of government authorities with whom to engage. While evictions and relocations - as well as resistance strategies against them - are far better documented now than they were two decades ago, the spaces in between those headlining moments are less well understood.

\section{Workers and entrepreneurs}

Above and beyond the localised struggles between street vendors and city authorities, a broader struggle for economic inclusion is playing out both within organising contexts and between street vendor organisations and the national state. This struggle relates to the fact that earnings from street vending can vary widely; while most street vendors are own-account workers with unstable earnings, poor access to health services and high exposure to occupational health and safety risks, a few become entrepreneurs who own or rent multiple stalls or stands, or occupy niche product sectors where earnings' potential is considerably higher. StreetNet International has addressed the resulting class structure explicitly by committing itself to supporting the poorest. But government policies and programmes often target the entrepreneurial end of the earnings continuum, meaning that the poorest vendors are left behind.

This differentiation has implications for street vendors' access to social protection and, more broadly, for formalisation approaches. One emerging model (from Brazil) allows "individual microenterprise operators" with low earnings to register for social security at subsidised rates, facilitating a type of formalisation for those at the lower end of the earnings continuum, but StreetNet organisers point out the potential of this model to undermine organising and collective 
action, given its framing of vendors as entrepreneurs instead of workers. A useful approach in future research agendas would be to better understand the possibilities of inclusion for the poorest vendors but also those own-account workers who are in between the vulnerable poor, on the one hand (e.g., elderly and disabled who may be granted privileged access to vending licences), and the entrepreneurial middle class (e.g., who can afford to pay to access microenterprise programmes) on the other. This middle group represents many ownaccount workers but gets relatively less attention in research and policy.

\section{Approaches to knowledge generation}

Finally, it is important for future research on street trade to find the middle ground in research design between in-depth case studies of a single location and quantitative analyses of large datasets that fold street vendors in with other informal sector enterprises. Structured comparisons of multiple locations drawing on both qualitative and quantitative data help reveal the complexity of street trade and its relationship to informality (Aliaga Linares and Roever 2019). Recent advances in theoretical and conceptual frameworks can serve as a foundation for better understanding of the links between urban dynamics, regulations and the day-to-day realities that street vendors face. Above all, investing in participatory approaches to knowledge generation that value street vendors' lived experiences and perceptions (Ogando and Harvey 2019) can provide insights that until now have remained on the margins of mainstream research. 


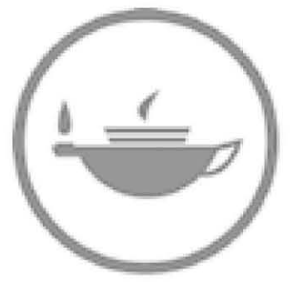

Taylor \& Francis Taylor \& Francis Group

http://taylorandfrancis.com 